\title{
OPTIMALISASI BADAN USAHA MILIK DESA DALAM MEMANFAATKAN POTENSI DESA (STUDI PADA DESA LAMPANAIRI KECAMATAN BATAUGA KABUPATEN BUTON SELATAN)
}

\author{
Darmin Hasirun 1 \\ ${ }^{1}$ Dosen Program Studi Peternakan Fakultas Pertanian dan Peternakan \\ Universitas Muslim Buton \\ Email: darmin.hasirun@gmail.com
}

\begin{abstract}
Abstrak: Badan Usaha Milik Desa (BUMDes) didirikan untuk mengoptimalkan pemanfaatkan potensi-potensi desa yang dapat menunjang perekonomian masyarakat, dengan adanya lembaga ini akan memotivasi warga desa untuk lebih terlibat langsung mengembangkan usaha-usaha pertanian, peternakan maupun keterampilan lainnya sehingga masyarakat dapat membangun desanya tanpa berbondong-bondong ke daerah perkotaan karena di desa kurang memberikan peluang pekerjaan yang lebih baik dibanding daerah kota. Hal inilah yang menjadi tugas bagi pengurus BUMDes untuk menjawab berbagai persoalan yang dihadapi oleh masyarakat desa. Desa Lampanairi merupakan salah satu desa yang mempunyai banyak potensi yang belum dimanfaatkan secara maksimal seperti kondisi lahan pertanian masih banyak yang kosong dan dibiarkan tanpa digarap oleh pemiliknya, peternakan yang dikelola oleh masyarakat desa belum banyak berproduksi untuk dijual ke pasar-pasar lokal, daerah maupun di luar daerah, potensi keindahan pantai di sepanjang pesisir desa masih sepi pengunjung, kegiatan budaya desa hanya dijadikan rutinitas tanpa dikemas secara aktraktif untuk menarik minat para wisatawan, banyaknya para pemuda yang memilih berangkat merantau ke daerah lain daripada bertahan di desanya karena kurangnya potensi desa yang bisa dimanfaatkan.
\end{abstract}

Kata kunci: Optimalisasi, Badan Usaha Milik Desa, Potensi Desa.

Abstract : The Village Owned Enterprise was established to optimize the utilization of village potentials that can support the community's economy, with this institution will motivate villagers to be more directly involved in developing agricultural, livestock and other skills businesses so that the community can build their villages without flocking to urban areas because in villages there are less job opportunities than urban areas. This is the duty of the management to answer various problems faced by the village community. Lampanairi Village is one village that has a lot of potential that has not been utilized optimally such as the condition of agricultural land which is still largely empty and left unused by its owner, farms managed by the village community have not produced much to sell to local markets, regions and in outside the area, the potential of the beauty of the beach along the coast of the village is still empty of visitors, village cultural activities are only used as a routine without being packaged attractively to attract tourists, many young people who choose to leave to migrate to other areas rather than survive in their villages because of the lack of village potential that can be used. Keywords: Optimization, Village-Owned Enterprises, Village Potential. 


\section{Pendahuluan}

Badan Usaha Milik Desa (BUMDes) merupakan lembaga yang dibentuk oleh masyarakat desa melalui dukungan pemerintah yang bertugas menyusun perencanaan, melaksanakan, mengawasi dan mengevaluasi kegiatan pemberdayaan masyarakat desa dengan memanfaatkan potensi desa secara efektif dan efisien.

BUMDes terlahir dari kebijakan pemerintah pusat melalui Undang-Undang Nomor 6 Tahun 2014 Tentang Desa yang mengamanatkan kepada pemerintah desa bersama dengan masyarakat agar membentuk BUMDes karena mempunyai peran yang sangat penting dalam mewujudkan desa mandiri dengan meningkatkan peranserta masyarakat desa dalam proses pembangunan.

BUMDes merupakan instrument pemberdayaan ekonomi lokal dengan berbagai ragam jenis usaha sesuai dengan potensi yang dimiliki desanya. Pengembangan potensi ini memiliki tujuan untuk meningkatkan kesejahteraan ekonomi warga desa melalui pengembangan usaha ekonomi. Disamping itu, keberadaan BUMDes juga membawa dampak terhadap peningkatan sumber pendapatan asli desa (PADes) yang memungkinkan desa untuk mampu melakukan sebuah pembangunan dan juga untuk peningkatan kesejahteraan secara lebih optimal. (Adawiyah,2018).

Berdasarkan pengamatan sementara penelitian terlihat bahwa pemanfaatan potensi desa pada Desa Lampanairi belum maksimal, hal ini dilihat dari kondisi lahan pertanian masih banyak yang kosong dan dibiarkan tanpa digarap oleh pemiliknya, peternakan yang dikelola oleh masyarakat desa belum banyak berproduksi untuk dijual ke pasar-pasar lokal, daerah maupun di luar daerah, potensi keindahan pantai di sepanjang pesisir desa masih sepi pengunjung, kegiatan budaya desa hanya dijadikan rutinitas tanpa dikemas secara aktraktif untuk menarik minat para wisatawan, banyaknya para pemuda yang memilih berangkat merantau ke daerah lain daripada bertahan di desanya karena kurangnya potensi desa yang bisa dimanfaatkan, hal ini diduga disebabkan oleh belum optimalnya kerja Badan Usaha Milik Desa seperti kurangnya pemahaman pengurus dalam mengidentifikasi potensi desa, pemetaan potensi dan skala prioritas program, kurangnya kegiatan pendampingan secara kelembagaan kepada pengurus tentang cara mengelola keuangan lembaga dengan efektif dan efisien sehingga usaha yang dibuat oleh BUMDes masih jalan ditempat bahkan mengalami kerugian, belum terdirinya kantor BUMDes yang dijadikan sebagai sarana untuk 
merencanakan, melaksanakan dan desa secara maksimal, kurangnya pola mengevaluasi setiap program kerja pengurus, serta masih kurangnya jumlah pengurus.

Begitu banyaknya potensi desa yang belum dilirik oleh masyarakat maupun pemerintah desa, bahkan ada pula yang sudah mengetahui potensi desanya tetapi bingung cara memanfaatkannya sehingga potensi tersebut terbelangkalai tanpa mendapatkan perhatian khusus dari pemerintah, misalnya potensi sumber daya alam yang ada di Desa Lampanairi antara lain: lahan peternakan ayam, kambing, sapi dan lain-lain, lahan perkebunan yang cukup luas dimanfaatkan untuk budidaya tanaman sayur-sayuran maupun buah-buahan, potensi laut yang dijadikan sebagai sarana obyek wisata bernama Pantai Jodoh serta potensi situs-situs budaya yang bernilai seni dan sejarah seperti sumur peninggalan Jepang dan Sungai Kaki Naue yang konon dijadikan sebagai tempat pemandian para tentara Jepang, Batu Wa Mbaani yang berbentuk seperti manusia, serta situs desa lainnya yang berhubungan erat dengan sejarah Kesultanan Buton.

Beberapa potensi tersebut terasa sulit digarap oleh kelompok masyarakat yang tergabung dalam Badan Usaha Milik Desa (BUMDes) karena masih kurangnya pemahaman masyarakat dalam pengembangan dan pemanfaatan potensi pendampingan dari pemerintah Kabupaten Buton Selatan menambah deretan masalah yang dihadapi oleh BUMDes, pengelolaan anggaran yang belum dilakukan secara professional, transparan dan akuntabel sehingga pemanfaatan anggaran kurang dialokasikan pada program kerja yang prioritas dan produktif.

Berdasarkan uraian permasalahan tersebut di atas, maka peneliti tertarik pengambil judul tentang "Optimalisasi Badan Usaha Milik Desa Dalam Memanfaatkan Potensi Desa (Studi Pada Desa Lampanairi Kecamatan Batauga Kabupaten Buton Selatan).

\section{Metode Penelitian}

Pendekatan yang digunakan dalam penelitian ini adalah pendekatan kualitatif (Moleong, 2010:138), dengan beberapa pertimbangan yakni; menyesuaikan metode kualitatif lebih mudah apabila berhadapan dengan kenyataan ganda. Metode ini menyajikan secara langsung hakikat hubungan antara peneliti dan informan. Metode ini lebih peka dan menyesuaikan diri bersama terhadap pola-pola nilai yang dihadapi oleh Badan Usaha Milik Desa dalam memanfaatkan potensi Desa Lampanairi sedangkan desain penelitiannya adalah desain deskriptif untuk menggambarkan atau menganalisis hasil 
penelitian tetapi tidak digunakan untuk membuat kesimpulan yang lebih luas (Sugiyono, 2011). Lokasi penelitian ini berada di Desa Lampanairi Kecamatan Batauga Kabupaten Buton Selatan dan jadwal penelitian yang dilaksanakan selama 3 bulan.

\section{Pembahasan}

Desa Lampanairi merupakan salah satu desa dari 5 desa di Kecamatan Batauga yang terletak di daerah pesisir, jarak tempuh yang dilalui dari Kota Baubau ke Desa Lampanairi sepanjang $\pm 28 \mathrm{Km}$ dengan lama perjalanan 44 menit, sedangkan dari Ibukota Kecamatan Batauga ke Desa Lampanairi hanya berjarak $\pm 8,2 \mathrm{Km}$ dengan lama perjalanan 14 menit. Wilayah Desa Lampanairi terdiri atas 4 dusun yaitu Dusun Kakenauwe I, Dusun Kakenauwe II, Dusun Kakenauwe III dan Dusun Langkaurusa.

$$
\text { Pusat Pemerintahan Desa }
$$

Lampanairi terletak di Dusun Kakenauwe II, dengan dibentuknya Desa Lampanairi, maka luas wilayah Desa Bola berkurang seluas wilayah Desa Lampanairi. Desa Lampanairi Kecamatan Batauga mempunyai batas-batas sebagai berikut:

a. Sebelah Utara berbatasan dengan Desa Hutan/ Tanah Negara;

b. Sebelah Timur berbatasan dengan Desa Bola; c. Sebelah Selatan berbatasan dengan Laut Flores;

d. Sebelah Barat berbatasan dengan Kelurahan Majapahit.

Berdasarkan hasil pendataan oleh pihak Desa Lampanairi Kecamatan Batauga Kabupaten Buton Selatan Provinsi Sulawesi Tenggara terkait jumlah penduduk, berjumlah 853 jiwa yang terbagi berdasarkan jenis kelamin laki-laki dan perempuan sebagai berikut : Laki-laki dengan jumlah 402 jiwa dan perempuan berjumlah 451 jiwa, dan jumlah Kepala Keluarga (KK) yang ada di Desa Lampanairi sebanyak $232 \mathrm{KK}$.

Badan Usaha Milik Desa yang ada di Desa Lampanairi sudah terbentuk sejak tahun 2017 tetapi lembaga ini belum berjalan maksimal dalam memanfaatkan potensi-potensi yang dimiliki oleh Desa Lampanairi, padahal secara geografis, maupun sosiologis, desa ini mempunyai beberapa potensi yang bisa dikembangkan untuk membantu meningkatkan perekonomian masyarakat desa.

Secara geografis desa ini mempunyai keindahan pantai bernama pantai jodoh, pantai ini sering dikunjungi oleh para wisatawan baik lokal, domestik maupun nasional pada saat liburan kerja, kondisi ini bisa dijadikan ajang untuk mempromosikan desa ke tingkat nasional dengan memaksimalkan penyediaan sarana dan 
prasarana pantai yang bisa dijadikan sebagai alat komersialisasi artinya pemanfaatan fasilitas tersebut harus dibayar oleh para pengunjung pantai dalam berupa retribusi yang akan dibagi secara adil antara Pemerintah Desa dan pemilik lahan, disamping itu terlihat pula kedatangan sekumpulan hewan laut (Penyu) di sepanjang pantai desa setiap tahunnya pada saat bulan purnama, penyupenyu ini datang untuk bertelur di pesisir pantai yang tentunya menjadi pemandangan menarik untuk dilestarikan bahkan dibudidayakan oleh masyarakat agar tetap menjaga habitat penyu yang semakin rusak akibat perbuatan manusia ataupun kondisi alam, rencana pemerintah desa dengan membuat penangkaran penyupenyu agar dijadikan sebagai edukasi bagi masyarakat tentang pentingnya melestarikan penyu-penyu tersebut, disamping itu para wisatawan dapat melihat secara langsung aktivitas penyu. Keberadaan hewan Penyu ini dirasakan oleh Pemerintah Desa sebagai fenomena yang unik karena dari beberapa desa/kelurahan yang ada di Kecamatan Batauga maupun Kabupaten Buton Selatan semakin jarang terlihat aktivitas Penyu datang bertelur di tepian pantai disebabkan ancaman dari tindakan oknum warga yang selalu mengambil telur penyu untuk diperjualbelikan, ataupun aktivitas penambangan pasir yang mengakibatkan penyu-penyu tersebut harus mencari habitat yang lebih aman dan nyaman untuk kelangsungan kehidupannya.

Secara sosiologis masyarakat di Desa Lampanairi mempunyai tradisi Ritual Pedhawua artinya ritual yang ditujukan untuk mempersembahkan atau memberikan hasil panen warga di tepian laut. Kegiatan ini dilakukan setiap peralihan musim barat maupun musim timur, ritual dipimpin langsung oleh para tetua adat. Di dalam acara ini, makanan persembahan diberikan di setiap empat sudut mata angin yang dipercaya oleh masyarakat setempat sebagai sarana untuk menolak bala sekaligus sebagai ungkapan rasa syukur kepada Tuhan Yang Maha Kuasa atas berkah dan rezeki yang diberikan selama proses peralihan musim, selama ritual ini warga setempat tidak boleh melakukan aktivitas selama 7 hari dan puncak ritual Pedhawua ini oleh para tetua adat melakukan prediksi / ramalan berdasarkan fenomena alam terhadap hasil panen warga yang dialami kedepannya di desa tersebut. Ritual ini dianggap sebagai potensi sosiologis yang sebenarnya BUMDes dapat menjadikannya sebagai ajang promosi budaya lokal (local wisdom) kepada para wisatawan agar memperkenalkan sejumlah tradisi peninggalan nenek moyang warga Desa Lampanairi sehingga bukan hanya 
wisata pantai saja yang dapat dinikmati oleh para pengunjung tetapi wisata budaya dapat menjadi pernak-pernik paket budaya yang terintegrasi secara langsung dengan kegiatan pemasaran hasil bumi dari warga setempat yang dikemas dalam kegiatan UMKM warga agar menawarkan produkproduk hasil panen warga kepada para pendatang yang menikmati liburan di desa tersebut.

\section{Gambar 1}

\section{Skema Rencana Pembangunan Wisata} Bahari Desa Lampanairi

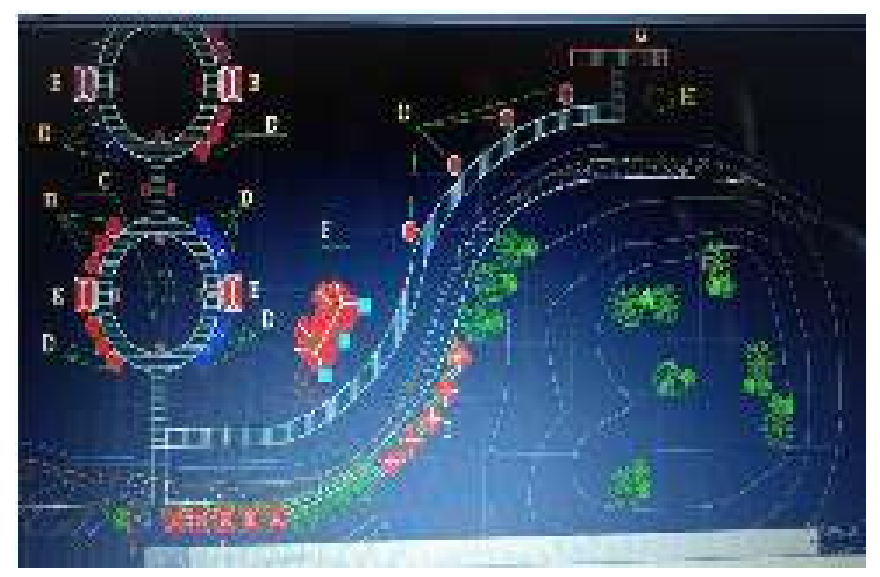

Sumber: Kantor Desa Lampanairi, 2019

Berdasarkan gambar skema ini terlihat bahwa adanya rencana pemanfaatan potensi desa yang ada di pesisir pantai seperti Situs Batu Licin, Situs Batu Wa Mbaani, Situs Tempat Singgah Daeng Para Pati serta penangkaran penyupenyu yang dibuat secara terintegrasi saling terhubung agar dapat mempermudah para wisatawan agar lebih menikmati keindahan alam di pesisir pantai dan penanaman nilainilai konsep wisata edukasi tentang pentingnya pelestarian hewan penyu bagi keseimbangan ekosistem di laut, ditambah pula dengan desain reklamasi pada bagian pinggir pantai yang ditanami oleh pohonpohon serta lapak dagangan bagi para pelaku UMKM untuk menjual hasil panen dan segala keperluan bagi para pendatang yang menikmati tempat wisata, pembuatan gazebo-gazebo layang yang ada di atas permukaan laut, desain ini dibuat agar pantai terlihat indah dan menarik minat para wisatawan. Dengan adanya Wisata Bahari akan dapat menambah pendapatan bagi BUMDes untuk memasarkan hasil-hasil bumi yang dikelola oleh warga setempat.

Pemanfaatan potensi bahari untuk dijadikan sebagai obyek wisata Desa Lampanairi, seperti halnya yang dilakukan oleh Desa Ponggok. Pelaku usaha pariwisata di Desa Ponggok membuat suatu objek dan atraksi wisata baru yang berisi pesan edukatif, kreatif, serta atraktif dengan mengambil konsep alam. Salah satu sektor yang bisa dimanfaatkan oleh masyarakat desa adalah pariwisata, yang dikemudian hari berkembang menjadi wisata minat khusus, yakni desa wisata. Melalui pengembangan desa wisata ini diharapkan bisa menjadi upaya untuk memberdayakan masyarakat setempat untuk lebih maju dan mandiri. Desa Ponggok telah berusaha memanfaatkan potensi-potensi yang mereka miliki dengan menjadikan desa mereka menjadi desa wisata dengan 
menonjolkan keindahan alam yang mereka miliki. Dalam pengelolaan desa wisata tentunya masyarakat diberi andil untuk ikutserta dalam upaya pengembangannya. Dengan adanya keikutsertaan masyarakat secara langsung dalam pengembangan desa wisata, maka bisa juga dimanfaatkan untuk usaha pemberdayaan masyarakat setempat (Eko Nur Fatmawati, 2015 dalam Arafat, 2018).

Keberadaan potensi pantai yang dimiliki oleh Desa Lampanairi tidak kalah menariknya dengan desa-desa yang lainnya karena desa ini sudah cukup banyak menyimpan berbagai keindahan alam pantainya seperti Pantai Jodoh yang belum digarap maksimal oleh BUMDes bekerjasama dengan pemilik lahan pantai tersebut, serta rencana pembangunan wisata bahari menghadirkan nuansa kreatif dan inovatif bagi pemanfaatkan potensi desa yang bernilai ekonomi dan dapat menguatkan kelembagaan BUMDes yang selama ini belum mendapatkan perhatian penuh dari pemerintah desa.

Sumber mata air yang sering dikonsumsi oleh warga setempat, baik untuk mencuci pakaian, air minum, bahan dasar pembuatan bangunan rumah, dan lain-lain. Di Desa Lampanairi mempunyai beberapa sumber mata air yang selalu mengalir setiap harinya, hal inilah yang dimanfaatkan oleh warga desa setempat bahkan warga desa/kelurahan lainnya seperti Desa Bola dan Kelurahan Majapahit juga mengambil sumber mata air yang berada di kawasan Desa Lampanairi karena debit airnya cukup memadai dalam menyuplai kebutuhan masyarakat di tiga desa/kelurahan, olehnya itu secara geografis desa ini cukup strategis karena telah berhasil memasok kebutuhan air warga di dua desa lainnya yang berdampingan, tetapi berdasarkan hasil observasi peneliti di lapangan kondisi mata air sudah cukup memprihatinkan karena kurang pedulinya masyarakat terhadap mata air tersebut akibat banyaknya penebangan dan pembakaran hutan yang berakibat pasokan debit air semakin hari semakin berkurang, padahal hutan adalah sebagai sarana penyangga dan penyuplai kebutuhan air harusnya dapat dilestarikan karena fungsi hutan salah satunya sebagai penampung air yang dibutuhkan oleh manusia, binatang maupun tumbuhtumbuhan. Disamping itu tidak adanya kegiatan pengontrolan secara ketat dan tindakan tegas dari pemerintah daerah Kabupaten Buton Selatan maupun dari Pemerintah Desa terhadap oknum yang sengaja melakukan pengrusakan hutan disekitar mata air tersebut. Hal inilah yang memperburuk kondisi mata air di Desa Lampanairi. 
Upaya yang dilakukan oleh Kepala Desa Lampanairi, La Ode Syarifuddin (baru menjabat 1 (satu) bulan semenjak penelitian ini berlangsung) melakukan perombakan karyawan BUMDES lama karena dianggap tidak berhasil melaksanakan tugas di bidang Unit Usaha Depot Air Minum, hal ini dilakukan agar terjadi kepengurusan baru dengan sistem manajemen pengelolaan BUMDes yang lebih inovatif dan kreatif dalam usaha Depot Air Minum sehingga air yang selama ini digunakan oleh warga desa dapat dimaksimalkan penggunaannya serta menjaga agar tidak semakin banyak oknum yang melakukan penebangan hutan secara sengaja yang dapat memperburuk kondisi mata air (hasil wawancara 15 November 2019). Pembentukan BUMDes yang bergerak di usaha air minum merupakan langkah yang cukup strategis untuk menjawab berbagai permasalahan yang dihadapi oleh Pemerintah Desa yaitu rendahnya kegiatan kewirausahaan masyarakat yang memanfaatkan potensi potensi desa, dan penggundulan kawasan hutan yang tidak jauh dengan sumber mata air karena dengan adanya badan usaha tersebut akan dapat merencanakan dan melaksanakan segala amanah yang telah ditetapkan dalam peraturan perundangundangan, seperti yang diungkapkan oleh La Ode Syarifuddin mengatakan bahwa disini ada banyak mata air yang digunakan oleh desa-desa lainnya, mereka hanya izin dari Pemerintah Desa Lampanairi untuk memasang pipa air yang disalurkan ke rumah-rumah warga, hal ini kami pikir bisa menjadi potensi yang dapat dikembangkan meskipun sekarang ini cukup banyak penebangan pohon-pohon yang dapat mengancam kondisi mata air semakin berkurang debit airnya. (hasil wawancara 14 November 2019).

Potensi lainnya yang selama ini belum dimanfaatkan secara maksimal oleh BUMDes adalah lahan pertanian dan peternakan, dimana warga bukan hanya bergantung pada hasil tangkapan ikan yang didapatkan setiap harinya tetapi juga hasil panen dan ternak menjadi andalan untuk memenuhi kebutuhan rumah tangganya. Tidak maksimalnya pemanfaatan lahan sehingga masyarakat desa merasakan kecilnya peluang pendapatan yang ada di desanya, hal ini mengakibatkan banyak para pemuda lebih memilih merantau di keluar daerah seperti ke Daerah Bangka Belitung, Kalimantan, Ambon, Papua dan lain-lain untuk memenuhi kebutuhan hidupnya yang susah didapatkan di kampung halamannya. Hal inilah yang seharusnya menjadi tugas BUMDes dalam menjawab permasalahan yang dihadapi oleh warga desa. 
Di Jepang kita mengenal dengan program One Village One Commodity (OVOC). OVOC merupakan program dengan memadukan konsep kawasan komoditas unggulan, yang pertama kali dikembangkan di Provinsi Oita Jepang, dengan menggerakan program satu desa satu komoditas, dan sukses mengangkat harkat desa miskin Oyama karena adanya hasil pertanian unggulan meskipun dengan skala kecil. (Tambunan, et. al., 2003 dalam Harmiati dan Zulhakim, 2017).

Hal inilah yang lagi digarap oleh Pemerintah Desa Lampanairi melalui BUMDes dengan memanfaatkan hasil pertanian masyarakat untuk dijadikan sebagai komiditas utama masyarakat desa sekaligus menambah pendapatan masyarakat dan BUMDes, salah satu contohnya akan ada rencana program pembuatan tepung terigu dengan bahan mentahnya diambil dari ubi lokal dan pengadaan alat-alat untuk pengolahan dari bahan mentah menjadi barang jadi yang siap dipasarkan ke luar Desa Lampanairi. Melihat potensi yang ada kebanyakan masyarakat juga bercocok tanam pada tanaman ubi sehingga bisa membuka peluang usaha baru yang belum pernah dilirik oleh desa-desa lain dalam memanfaatkan potensi tersebut.

Pemberian kesempatan kepada pengurus BUMDes kedepannya adalah salah satu upaya mengurangi tingkat pengangguran karena akan ada pemberdayaan para petani, pelibatan warga dalam pengolahan hasil pertanian menjadi tepung terigu, tenaga penjualan produk yang bertugas menyebarkan produk tersebut ke pasar-pasar yang membutuhkan tepung terigu, bukan hanya sekedar berpengaruh pada penyerapan tenaga kerja lokal tetapi dapat menciptakan tenaga wirausaha baru yang memanfaatkan tegung terigu buatan desa tersebut. Hal inilah yang masih direncanakan oleh Kepala Desa Lampanairi untuk direalisasikan sebagai bagian dari solusi menjawab berbagai permasalahan warga desa.

Masuknya program dana desa yang telah masuk sejak tahun 2015 sampai sekarang, sudah terlihat adanya perubahan pola pikir serta kondisi masyarakat desa ke arah yang lebih baik seperti pemanfaatan potensi mata air untuk dijadikan usaha, meskipun hal ini belum cukup menjawab beberapa permasalahan yang dihadapi oleh masyarakat desa. Pembentukan BUMDes Kembang Jaya dengan unit usaha bernama Depot Air Minum Mata Wandoke diharapkan dapat memaksimalkan pemanfaatan potensi alam tersebut, sebagaimana dalam amanah UndangUndang Nomor 6 Tahun 2014 Tentang Desa pada pasal 89 berbunyi hasil usaha BUM Desa dimanfaatkan untuk: a. pengembangan 
usaha; dan b. Pembangunan Desa, pemberdayaan masyarakat Desa, dan pemberian bantuan untuk masyarakat miskin melalui hibah, bantuan sosial, dan kegiatan dana bergulir yang ditetapkan dalam Anggaran Pendapatan dan Belanja Desa.

Peraturan di atas telah memberikan arah baru bagi warga dan pemerintah desa untuk mengembangkan usaha rakyat yang berbasis pada potensi lokal agar masyarakat miskin yang ada di desa semakin diberdayakan dan dilibatkan dalam berbagai aktivitas pembangunan, tentunya setiap program BUMDes harus dapat menciptakan keberpihakan kepada warga miskin (pro poor), dengan mengalokasikan dana desa kepada BUMDes sebesar-besarnya demi kepentingan warga desa.

\section{Tabel 1}

Daftar Potensi Desa Lampanairi

\begin{tabular}{|c|l|c|c|}
\hline No & \multicolumn{1}{|c|}{$\begin{array}{c}\text { Nama } \\
\text { Potensi }\end{array}$} & Kondisi & Keterangan \\
\hline 1 & $\begin{array}{l}\text { Sumber Mata } \\
\text { Air }\end{array}$ & Baik & $\begin{array}{c}\text { Dikelola Oleh } \\
\text { BUMDes }\end{array}$ \\
\hline 2 & Pantai Jodoh & Baik & $\begin{array}{c}\text { Dikelola Oleh } \\
\text { Pribadi }\end{array}$ \\
\hline 3 & $\begin{array}{l}\text { Lahan } \\
\text { Pertanian } \\
\text { (Ubi Kayu } \\
\text { dan Sayur- } \\
\text { Sayuran) }\end{array}$ & Baik & $\begin{array}{l}\text { Dikelola Oleh } \\
\text { Pribadi (Hasil } \\
\text { Panen Masih } \\
\text { Minim) }\end{array}$ \\
\hline 4 & $\begin{array}{l}\text { Peternakan } \\
\text { Sapi, } \\
\text { Kambing dan } \\
\text { Ayam) }\end{array}$ & Baik & $\begin{array}{c}\text { Dikelola Oleh } \\
\text { Pribadi (Produksi } \\
\text { Masih Minim) }\end{array}$ \\
\hline 5 & $\begin{array}{l}\text { Batu Wa } \\
\text { Mbaani }\end{array}$ & Baik & $\begin{array}{c}\text { Tidak Dikelola } \\
\text { (Legenda } \\
\text { Masyarakat Desa } \\
\text { Lampanairi, Batu } \\
\text { mirip Manusia) }\end{array}$ \\
\hline 6 & $\begin{array}{l}\text { Situs Batu } \\
\text { Licin }\end{array}$ & $\begin{array}{l}\text { Kurang } \\
\text { Terawat }\end{array}$ & $\begin{array}{c}\text { Tidak Dikelola } \\
\text { (Legenda }\end{array}$ \\
\hline
\end{tabular}

\begin{tabular}{|c|c|c|c|}
\hline & & & $\begin{array}{c}\text { Masyarakat Desa } \\
\text { Lampanairi) }\end{array}$ \\
\hline 7 & $\begin{array}{l}\text { Tempat } \\
\text { Singgahnya } \\
\text { Daeng Para } \\
\text { Pati }\end{array}$ & $\begin{array}{l}\text { Kurang } \\
\text { Terawat }\end{array}$ & $\begin{array}{l}\text { Tidak Dikelola } \\
\text { (Legenda } \\
\text { Masyarakat Desa } \\
\text { Lampanairi) } \\
\end{array}$ \\
\hline 8. & $\begin{array}{l}\text { Sumur } \\
\text { Peninggalan } \\
\text { Jepang }\end{array}$ & $\begin{array}{l}\text { Kurang } \\
\text { Terawat }\end{array}$ & $\begin{array}{c}\text { Tidak } \\
\text { Dikelola/Kotor }\end{array}$ \\
\hline 9. & $\begin{array}{l}\text { Sungai Kaki } \\
\text { Naue }\end{array}$ & $\begin{array}{c}\text { Kurang } \\
\text { Terawat }\end{array}$ & Tidak Dikelola \\
\hline 10. & $\begin{array}{l}\text { Acara Adat } \\
\text { Pedhawua }\end{array}$ & Baik & $\begin{array}{c}\text { Dilaksanakan Oleh } \\
\text { Tetua Adat } \\
\text { Bersama } \\
\text { Pemerintah dan } \\
\text { Masyarakat Desa } \\
\end{array}$ \\
\hline 11. & $\begin{array}{l}\text { Sumber Daya } \\
\text { Manusia }\end{array}$ & $\begin{array}{c}\text { Kurang } \\
\text { Diberdayakan }\end{array}$ & $\begin{array}{c}\text { Program } \\
\text { pemberdayaan } \\
\text { ekonomi } \\
\text { masyarakat desa } \\
\text { belum sepenuhnya } \\
\text { digerakan oleh } \\
\text { BUMDes } \\
\end{array}$ \\
\hline
\end{tabular}

Sumber: Hasil Observasi, 2019.

Berdasarkan tabel tersebut di atas terlihat bahwa sebagian besar potensi desa kurang dikelola oleh BUMDes Desa Lampanairi sehingga banyak yang terbengkalai tanpa mendapatkan sentuhan dana dan program pengembangan potensi desa, misalnya Sumur Peninggalan Jepang yang terlihat tidak terurus sehingga kotor dan hanya menjadi cerita rakyat yang ada di desa setempat, padahal situs sejarah ini dapat menjadi daya tarik para pengunjung (wisatawan) untuk mengetahui sejarah Desa Lampanairi di masa penjajahan jepang, begitu juga dengan lahan pertanian yang lebih banyak menghasilkan ubi kayu dan sayur-sayuran, hewan-hewan ternak seperti sapi, kambing dan ayam, terlihat hanya hanya diurus oleh warga sendiri tanpa mendapatkan perhatian dari pengurus BUMDes setempat, Pemerintah 
Desa Lampanairi maupun Pemerintah Daerah Kabupaten Buton Selatan seperti pemberian bantuan/insentif, kurangnya bantuan peralatan, maupun pelatihan kepada para petani dan peternak, kondisi tersebut tidak memberikan dampak positif bagi kemajuan pembangunan desa, pengurangan pengangguran dan pengentasan kemiskinan masyarakat desa.

Potensi yang tidak kalah pentingnya adalah sumber daya manusia yang belum sepenuhnya dilibatkan dalam upaya peningkatan ekonomi warga, seharusnya dengan adanya BUMDes dapat menggerakan ekonomi desa melalui berbagai upaya pendampingan, pemberdayaan dan pengelolaan sumber daya yang ada di desa karena semua potensi akan sangat ditentukan oleh kemampuan sumber daya masyarakat untuk mengelolanya. Selama pendirian BUMDes di Desa Lampanairi belum terlihat perubahan yang signifikan tentang kondisi masyarakat yang lebih memilih bekerja di luar desa bahkan keluar daerah karena kurangnya pelibatan masyarakat dalam upaya memenuhi kebutuhan ekonominya.

Penduduk (SDM) hendaknya tidak hanya dilihat sebagai obyek (penikmat) hasil pembangunan (industrialisasi) tetapi sekaligus sebagai subyek (pelaku) pembangunan. Kebijakan pembangunan perlu berorientasi pada pertumbuhan ekonmi, pemerataan dan dapat meniciptakan kesinambungan pembangunan dengan memanfaatkan potensi sumber daya ekonomi daerah. (Soewartoyo \& Soetopo, 2009).

BUMDes juga bisa berperan sebagai pihak yang menjadi agen untuk menampung segala produksi yang dihasilkan dari olahan pertanian maupun peternakan, misalnya para petani desa hanya bertugas mengelola lahan pertanian atau peternakannya dengan maksimal, hasilnya akan dibeli oleh BUMDes untuk di jual kembali di pasar-pasar lokal maupun luar daerah dengan harga yang kompetitif, sehingga para petani/peternak tidak perlu lagi sibuk menjadi hasilnya ke pasar tetapi cukup melakukan kegiatan pertanian dan peternakan dari proses awal hingga masa panen.

Nama BUMDes : Kembang Jaya

Bergerak di Bidang : Depot Air Minum

Mata Wandoke

Tabel 2

Daftar Nama-Nama Pengurus BUMDes

\begin{tabular}{|c|c|c|c|c|c|}
\hline No & Nama & $\begin{array}{c}\text { Jenis } \\
\text { Kelamin }\end{array}$ & Usia & Jabatan & $\begin{array}{c}\text { Pekerjaan } \\
\text { Lain } \\
\text { Selain } \\
\text { Pengurus } \\
\text { BUMDes }\end{array}$ \\
\hline 1 & Darmin & Laki-Laki & $\begin{array}{c}30 \\
\text { Tahun }\end{array}$ & Ketua & $\begin{array}{c}\text { Pegawai } \\
\text { PERUSDA }\end{array}$ \\
\hline 2 & $\begin{array}{c}\text { Yuliana, } \\
\text { S.Kom. }\end{array}$ & Perempuan & $\begin{array}{c}25 \\
\text { Tahun }\end{array}$ & Bendahara & $\begin{array}{c}\text { PTT } \\
\text { Kantor BK } \\
\text { \& PDM } \\
\text { Kab.Buton } \\
\text { Selatan }\end{array}$ \\
\hline
\end{tabular}

Sumber: Kantor Desa Lampanairi, 2019. 
Berdasarkan tabel tersebut di atas, peneliti dapat mengidentifikasi bahwa pengurus BUMDes Kembang Jaya yang bergerak di bidang Depot Air Minum belum mencukupi dari segi jumlah karena banyaknya potensi desa yang belum digarap dengan baik seperti potensi pantai beserta hewan-hewan penyu, situs budaya, UMKM yang bergerak dalam pemasaran hasil pertanian dan peternakan. Hal inilah yang menjadi tugas dari pemerintah desa, pengurus BUMDes maupun masyarakat desa agar saling bahu membahu membangun desa demi kepentingan masyarakat desa. Idealnya setiap perusahaan mempunyai sekretaris, bendahara manajer-manajer bidang pemasaran, bidang inovasi dan kreativitas, bidang keuangan, dan lain-lain. Hal inilah yang menyebabkan sistem manajemen BUMDes belum berjalan dengan baik, ditambah lagi dengan sistem pembukuan laporan penggunaan keuangan yang cukup ketat dapat menambah beban 2 (dua) orang pengurus BUMDes.

Permasalahan tersebut sama halnya yang dialami oleh BUMDes KMS Desa Sidoasri belum optimal dalam manajemen pengelolaan usaha sehingga belum bisa memberikan manfaat yang signifikan bagi anggota, pemerintah desa maupun masyarakat, Untuk para anggotanya BUMDes KMS Desa Sidoasri belum bisa memberikan kesejahteraan kepada para anggotanya, dari delapan anggota resmi, hanya 2 anggota yang mendapatkan gaji dari BUMDes, dan gaji yang diterima karyawan masih terlalu kecil untuk membantu meningkatkan taraf ekonomi mereka. Untuk Pemerintah Desa sendiri BUMDes dirasa belum optimal, BUMDes memang sudah memberikan tambahan kas bagi desa, namun sedikitnya jumlah kas yang masuk yang diakibatkan oleh rendahnya omzet BUMDes. (Kusuma, 2018).

Berdasarkan Permen DPDTT pada pasal 10 berbunyi: Susunan kepengurusan organisasi pengelola BUM Desa terdiri dari: a. penasihat; b. pelaksana operasional; dan c. pengawas. Jabatan penasehat secara langsung dipegang oleh Kepala Desa sebagai ex officio yang berkewajiban memberikan nasihat kepada Pelaksana Operasional dalam melaksanakan pengelolaan BUM Desa; memberikan saran dan pendapat mengenai masalah yang dianggap penting bagi pengelolaan BUM Desa; dan mengendalikan pelaksanaan kegiatan pengelolaan BUM Desa. Olehnya itu peran kepala desa dalam penguatan kelembagaan BUMDes dianggap sangat penting dengan melakukan pembinaan dan pengendalian segala kegiatan operasional pengurus BUMDes agar searah dengan program kerja pemerintah desa dan sesuai dengan harapan masyarakat desa yang 
telah termuat dalam rencana pembangunan setiap tahunnya.

Sedangkan pelaksana operasional mempunyai tugas mengurus dan mengelola BUM Desa sesuai dengan Anggaran Dasar dan Anggaran Rumah Tangga yang berkewajiban: a. melaksanakan dan mengembangkan BUM Desa agar menjadi lembaga yang melayani kebutuhan ekonomi dan/atau pelayanan umum masyarakat Desa; b. menggali dan memanfaatkan potensi usaha ekonomi Desa untuk meningkatkan Pendapatan Asli Desa; dan c. melakukan kerjasama dengan lembagalembaga perekonomian Desa lainnya.

Ketiga kewajiban tersebut di atas, saling berhubungan dalam upaya menggali dan memanfaatkan potensi desa agar memenuhi kebutuhan masyarakat serta dapat memberikan pelayanan yang sesuai dengan permasalahan yang dihadapi dengan menjalin kerjasama antara BUMDes dan lembaga-lembaga perekonomian lainnya yang dapat memberikan keuntungan ekonomi bagi pendapatan BUMDes hal ini diperlukan kreativitas dan inovasi para pengurus BUMDes dalam merespon segala peluang yang bisa bisa dijadikan sebagai kekuatan bagi BUMDes untuk bergerak dan melaksanakan tugasnya agar mencapai tujuan yang diharapkan.

Menurut Permen DPDTT pada pasal 14 menyatakan bahwa persyaratan menjadi
Pelaksana

Operasional

meliputi: masyarakat Desa yang mempunyai jiwa wirausaha, berdomisili dan menetap di Desa sekurang-kurangnya 2 (dua) tahun, berkepribadian baik, jujur, adil, cakap, dan perhatian terhadap usaha ekonomi Desa; dan pendidikan minimal setingkat SMU/Madrasah Aliyah/SMK atau sederajat; Aturan tersebut di atas sejalan dengan semangat pemerintah dalam membentuk desa mandiri yang didapatkan melalui kegiatan kewirausahaan desa, tentunya pengurus BUMDes harus memahami prinsip-prinsip dalam berwirausaha, semangat berwirausaha dan adanya keinginan untuk melakukan perubahan yang lebih melalui kegiatan wirausaha desa, sedangkan aturan tentang domisili dan menetap yang ditetapkan sekurang-kurangnya 2 tahun masih dianggap wajar karena pengurus BUMDes diharapkan adalah orang-orang yang sudah memahami memetakan potensi desa agar bisa dijadikan kegiatan wirausaha masyarakat desa dan tingkat pendidikan pengurus yang setingkat dengan sekolah menengah umum juga perlu dilakukan secara standar minimum, artinya semakin tinggi pemahaman pengurus BUMDes tentang kegiatan wirausaha semakin berpeluang menumbuhkembangkan BUMDesnya menjadi lembaga wirausaha 
yang mengambil beberapa potensi desa agar bisa dikelola secara ekonomis.

Temuan penelitian di lapangan bahwa pengurus BUMDes belum sesuai dengan harapan yang diamanatkan dalam peraturan meskipun secara administratif sudah memenuhi syarat seperti tingkat pendidikan pengurus yang sudah memadai, dan penduduk desa setempat yang sudah menetap lebih dari 2 tahun, sedangkan semangat wirausahanya belum menunjukan perubahan signifikan untuk membawa desa mencapai kemajuan dalam pembangunan di segala bidang utamanya bidang yang menjadi fokus diantaranya pertanian, peternakan serta kegiatan pariwisata yang mengandalkan potensi budaya dan kekayaan alam. Seperti yang tercantum dalam Permendes, PDTT No 4 Tahun 2015 Tentang Pendirian, Pengurusan Dan Pengelolaan, Dan Pembubaran Badan Usaha Milik Des pada pasal 3 menyatakan bahwa Pendirian BUM Desa bertujuan: (1).Meningkatkan perekonomian Desa; (2).Mengoptimalkan aset Desa agar bermanfaat untuk kesejahteraan Desa; (3).Meningkatkan usaha masyarakat dalam pengelolaan potensi ekonomi Desa; (4).Mengembangkan rencana kerja sama usaha antar desa dan/atau dengan pihak ketiga; (5).Menciptakan peluang dan jaringan pasar yang mendukung kebutuhan layanan umum warga; (6).Membuka lapangan kerja; (7).Meningkatkan kesejahteraan masyarakat melalui perbaikan pelayanan umum, pertumbuhan dan pemerataan ekonomi Desa; dan (8).Meningkatkan pendapatan masyarakat Desa dan Pendapatan Asli Desa.

Berdasarkan Permen DPDTT di atas dapat diidentifikasi bahwa pendirian BUM Desa salah satunya adalah meningkatkan usaha masyarakat dalam pengelolaan potensi ekonomi desa untuk menambah pendapatan masyarakat desa serta mewujudkan kesejahteraannya, maka kehadiran BUMDes merupakan harapan besar bagi masyarakat desa untuk dapat mengekplorasi sumber daya yang ada di kawasan desa agar bernilai ekonomis bagi masyarakat, seperti pemanfaatan mata air desa dengan mendirikan BUMDes Kembang Jaya yang bergerak di bidang Depot Air Minum, agar dapat memasok kebutuhan air dan mengkomersialisasikan potensi tersebut sehingga laba atau pendapatan dari hasil penjualan menjadi pendapatan bagi pengurus BUMDes dan sebagian disetor kepada Pemerintah Desa yang akan masuk sebagai kas desa atau biasanya disebut PADes (Pendapatan Asli Desa), dengan melakukan pemungutan retribusi setiap bulannya yang nantinya hasil dari retribusi tersebut agar dibagi sebagian untuk perusahaan BUMDes dan sebagian lagi untuk kas desa. 


\section{Kesimpulan}

Kesimpulan dalam penelitian ini adalah penguatan kelembagaan Badan Usaha Milik Desa dalam memanfaatkan potensi Desa Lampanairi Kecamatan Batauga Kabupaten Buton Selatan belum maksimal hal ini dilihat dari pengurus BUMDes Kembang Jaya yang bergerak di bidang Depot Air Minum belum mencukupi dari segi jumlah karena banyaknya potensi desa yang belum digarap dengan baik seperti potensi pantai beserta hewanhewan penyu, situs budaya, UMKM yang bergerak dalam pemasaran hasil pertanian dan peternakan. Hal inilah yang menjadi tugas dari pemerintah desa, pengurus BUMDes maupun masyarakat desa agar saling bahu membahu membangun desa demi kepentingan masyarakat desa. Idealnya setiap perusahaan milik desa minimal mempunyai sekretaris, bendahara manajer-manajer bidang pemasaran, bidang inovasi dan kreativitas, bidang keuangan, dan lain-lain. Hal inilah yang menyebabkan sistem manajemen BUMDes belum berjalan dengan baik, ditambah lagi dengan sistem pembukuan laporan penggunaan keuangan yang cukup ketat dapat menambah beban 2 orang pengurus BUMDes., pengurus BUMDes belum sesuai dengan harapan yang diamanatkan dalam peraturan meskipun secara administratif sudah memenuhi syarat seperti tingkat pendidikan pengurus yang sudah memadai, dan penduduk desa setempat yang sudah menetap lebih dari 2 tahun, sedangkan semangat wirausahanya belum menunjukan perubahan signifikan untuk membawa desa mencapai kemajuan dalam pembangunan disegala bidang utamanya bidang yang menjadi fokus diantaranya pertanian, peternakan serta kegiatan pariwisata yang mengandalkan potensi budaya dan kekayaan alam.

Saran penelitian perlunya upaya optimalisasi BUMDes Lampanairi dengan cara menambah jumlah pengurus BUMDes agar dapat mengelola beberapa unit usaha yang berhubungan dengan usaha pengembangan potensi desa, penambahan bantuan berupa dana bagi operasionalisasi BUMDes agar lebih maksimal dalam bekerja, pendirian kantor bagi pengurus, dan lebih banyak mengadakan pendidikan dan pelatihan bagi pengurus seperti pelatihan pengelolaan keuangan, pelatihan pemetaan potensi desa, dan peningkatan kapasitas pengurus, perlunya pengembangan dalam memanfaatkan potensi desa yang bernilai ekonomi agar dapat menyerap tenaga kerja khususnya bagi warga di Desa Lampanairi. 


\section{Daftar Pustaka}

Adawiyah, Robiatul. 2018. Strategi Pengembangan Badan Usaha Milik Desa (BUMDes) Berbasis Aspek Modal Sosial (Studi pada BUMDes Surya Sejahtera, Desa Kedungturi, Kecamatan Taman, Kabupaten Sidoarjo). Program Studi Ilmu Administrasi Negara, FISIP, Universitas Airlangga.

Anifa, Kun W. 2011. Strategi Pengembangan Organisasi Prima. Cendekia Yogyakarta. Jurnal Managemen. Hal 213-234.

Arafat, Muhammad Yasser. 2018. Badan Usaha Milik Desa dan Pemberdayaan Ekonomi Masyarakat Desa (Studi Pada BUMDes Tirta Mandiri, Desa Ponggok, Kecamatan Polanharjo, Kabupaten Klaten. Fakultas Ilmu Sosial dan Humaniora. Universitas Islam Negeri Sunan Kalijaga

Davis, Keith dan John W. Newstrom. 1994. Perilaku Dalam Organisasi. Jakarta: Erlangga.

Harmiati dan Abdul Aziz Zulhakim. 2017. Eksistensi Badan Usaha Milik Desa (BUMDES) Dalam Mengembangkan Usaha Dan Ekonomi Masyarakat Desa Yang Berdaya Saing Di Era Masyarakat Ekonomi ASEAN. Fakultas Ilmu Sosial dan Ilmu Politik. Universitas Hazairin Bengkulu.

Kusuma, Tedi. 2018. Pembentukan Dan Pengelolaan Bumdes (Badan Usaha Milik Desa) Karya Mandiri SejatI (Studi Kasus di Desa Sidoasri Kec. Candipuro Kab. Lampung Selatan. Fakultas Ilmu Sosial Dan Ilmu Politik Universitas Lampung. Bandar Lampung.
Moleong, Lexy J. 2010, Metodologi Penelitian Kualitatif PT.Remaja Rosda Karya, Bandung.

Peraturan Menteri Desa, Pembangunan Daerah Tertinggal, Dan Transmigrasi Republik Indonesia Nomor 4 Tahun 2015 Tentang Pendirian, Pengurusan Dan Pengelolaan, Dan Pembubaran Badan Usaha Milik Desa.

Saputra, Anom Surya. 2015. Badan Usaha Milik Desa:Spirit Usaha Kolektif Desa. Kemendesa PDTT.

Siagian, Sondang P. 2008. Manajemen Sumber Daya Manusia. Jakarta: Bumi Aksara.

Soewartoyo \& Soetopo, Toni. 2009. Potensi Sumber Daya Alam Dan Peningkatan Kualitas Sumber Daya Manusia Di Kawasan Masyarakat Pesisir, Kabupaten Bangka. Pusat Penelitian Kependudukan- Lembaga Ilmu Pengetahuan Indonesia (PPKLIPI).

Sugiyono, MPA, 2011. Metode Penelitian Campuran, Edisi Ke-13 CV. Alavabeta, Bandung.

Sutarto. 2002. Dasar-Dasar Organisasi. Yogyakarta:Gajah Mada University Press.

Undang-Undang Republik Indonesia Nomor 6 Tahun 2014 Tentang Desa. 